\title{
NHÂN MỘT TRƯỜnG HợP BƯỚU CHU BÀO PHỔI TRÁI TÁI PHÁT (HEMANGIOPERICYTOMA)
}

Văn Tần ${ }^{* *}$, Văn Hùng Dũng ${ }^{* *}$, Nguyễn Văn Việt Thành*, Đoàn Hùng Dũng*, Duơng Thanh Hải*

\section{TÓM TẮT}

Bướu mạch máu chu bào phổi (Hemangioperi cytoma) rất hiếm. Chúng tôi gặp đầu tiên trường hợp trên. Định bệnh ban đầu không được mà gọi là bướu lành tính nên cho bệnh nhân về. Hơn 10 năm sau, bướu tái phát nên bệnh nhân nhập viện lại.

Bệnh nhân Trần thị Kim H, sanh năm 1970, có chồng và 4 con, làm ruộng ở An thới Đông, huyện Cần Giờ, nhập viện ngày 26/9/2019 vì bướu phổi trái tái phát. $\mathrm{BN}$ chỉ có triệu chứng nhức đầu, chóng mặt 2 năm gần đây sau 10 năm mổ phổi tại BV Bình Dân . Khám không thấy gì lạ, ngoài bướu phổi trái. Các xét nghiệm đều bình thường, ngoài ra hơi thiếu máu.

Ban đầu tính mổ nội soi nhưng không được vì gây mê phổi trái không xẹp. 1 tuần sau quyết định mổ lại, lần nầy mổ mở. Lúc mổ thấy bướu dinh thành ngực và phổi, nên sau khi gở dính, cắt bỏ bướu, khâu cầm máu bằng Vicyl 3.0. Đóng ngực và dẫn lưu màng phổi. Sau mổ, diễn tiến bình thường và nằm viện 15 ngày. Giải phẫu bệnh mô bướu: lần đầu sinh thiết qua hướng dẫn MSCT, thấy ung thư không tế bào nhỏ, biệt hóa kém ; lần mổ làm sinh thiết với kết quả lympho tế bào lớn ; lần thứ ba với kỹ thuật hóa mô miễn dịch cho kết quả là bướu mạch chu bào phổi (lung hemangiopericytoma). Chúng tôi cân nhắc hóa trị cho bệnh nhân hay không.

Tù khóa: Bướu mạch chu bào phổi (hemangiocytoma)
A CASE OF RECUR

\section{HEMANGIOPERICYTOMA OF THE LUNG}

\section{SUMMARY}

Hemangiopericytoma, of the lung is seldom ever bengin or malignant. We met a hemangiopericytoma firstly in the lung. The diagnosis at that time is vascular tumor, it is benign so no chemotherapy. About over 10 years, the tumor recur, so the patient come back.

Patient Tran thi Kim H., date naissance 1970, mariage with 4 children, farmer. Live at An thoi Đong, Can Gio district, admitted $26 / 9 / 2019$, by recurrent tumor of the left lung. After 10 years of lung operation, patient has symptom of headache and vertiginous in two recent years. At Binh Dan hospital, in examination, no is abnormal except the tumor of the inferior left lung. Labo data is normal, except a mild anemia.

Firstly, we decide remove the tumor by thoracotomy, but the left lung cannot be deflated so the operation is postponed. A week after, a left thoracotomy, we saw the tumor adhere to the thoracic wall and to the left lung; when we dissected the tumor was ruptured. We removed all of tumor with a partial left inferior lung and vascular control with Vicryl 3.O. We drain and close the thorax. Post- operation was stable and patient was discharged after 15 days .

* Bệnh viện Bình Dân

** ĐH Y khoa Pham Ngoc Thach Ngườ chịu trách nhiệm khoa học: GS Văn Tần Ngày nhận bài: 01/02/2019 - Ngày Cho Phép Đăng: 23/03/2020 Phản Biện Khoa học: PGS.TS. Đặng Ngocc Hùng GS.TS. Lê Ngoc Thành 
Biopsy with MSCT, the diagnosis is undifferentiated non small cell lung cancer. But at opened operation, the diagnosis is lymphocyte with big cell B. After that, the diagnosis is hemangiopericytoma of the lung (immunohistochemistry test). For this patient, we hesite the chemotherapic treatment or not.

Key word: Hemangiopericytoma.

\section{CA LÂM SÀNG}

Bướu mạch máu chu bào phổi (Hemangioperi cytoma) rất hiếm. Chúng tôi gặp đầu tiên trường hợp trên. Định bệnh ban đầu không được mà gọi là bướu lành mạch máu nên mổ xong, cho bệnh nhân về. Hơn 10 năm sau, bướu tái phát nên bệnh nhân nhập viện lại.

Bệnh nhân Trần thị Kim H, 1970, số lưu trữ 2019/24341. Ở An Thới Đông, Cần Giờ, TP
HCM. Nhập viện ngày 26/9/2019, vì bướu thùy dưới phổi trái tái phát. Đã mổ cắt bướu phổi trái năm 2009 tại BV BD. BN đã điều trị tại BV Ung bướu, TP HCM 20 ngày, MSCT phát hiện bướu mạch máu nên chuyển BV Bình Dân.

Bệnh sử: Trong khoảng 2 năm, $\mathrm{BN}$ bị chóng mặt, nhức đầu, sụt cân, đau lưng. Chụp CT tại Hòa Hảo, phát hiện bướu ở phổi, dạng mạch máu. BN sanh 4 con, mổ triệt sản năm 30 tuổi.

Lần mổ đầu, mở ngực trái, cắt bướu, nằm viện 14 ngày. Giải phẫu bệnh: bướu lành nên cho về, không hóa trị. Từ lúc về đến nay, không triệu chứng. 2 năm gần đây, người hay nóng lạnh, 2 tháng nay, thường bị cảm sốt, không đau ngực. Hiện tại, bướu tái phát ở thùy dưới, trên 10 năm, không đau, chỉ khó chịu ngực bên trái. Khám bệnh viện huyện Cần Giờ khuyên lên $\mathrm{BV}$ Bình Dân để mổ.

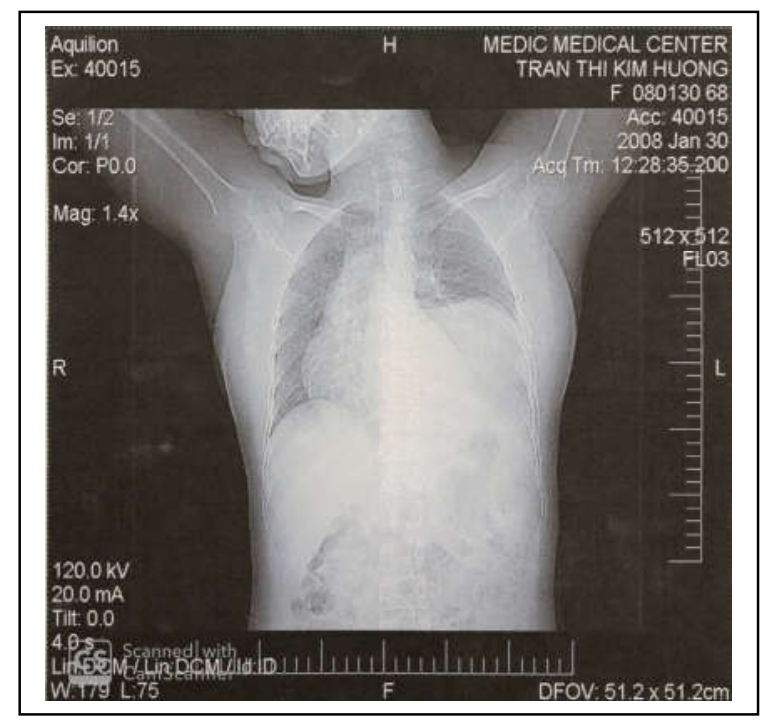

\section{Hình 1: X quang phổi năm 2008}

Là phụ nữ vóc dáng vừa phải, ngực trái có sẹo vết mổ qua liên sườn 5-6 dài từ đường ngực trước ra đường ngực sau, có gãy xương sườn 6 do đặt dụng cụ banh ngực. Lần đầu, mở ngực trái, cắt bướu từng mảnh, lấy sạch, rửa xoang màng phổi, đóng ngực, đặt dẫn lưu. 3 ngày sau mổ rút dẫn lưu, vết mổ lành, phổi nở tốt. 7 ngày sau, giải phẫu bệnh cho biết mô bướu lành tính nên không cho hóa trị. Hơn 10 năm, bệnh nhân không có triệu chứng gì về phổi nên không tái khám. 2 năm gần đây, người bệnh thấy nhức đầu, chóng mặt và 1 tuần trước, vì khó chịu bên ngực trái nên đến khám bệnh BV huyện Cần Giờ, chụp phổi thấy bướu ở đáy phổi trái, chuyển BV Bình Dân. 
Chụp CT 32 dãy có tiêm thuốc cản quang, tiêm cản quang vùng màng phổi đáy phổi trái. thực hiện các lớp cắt liên tục dày $03 \mathrm{~mm}$ qua Không có tổn thương khác. Chẩn đoán ban đầu là vùng ngực. Vùng đáy phổi trái có tổn thương đậm theo dõi bướu màng phổi đáy phổi trái. độ mô $\mathrm{D}=17$ x $22 \mathrm{~mm}$, tăng quang mạnh sau
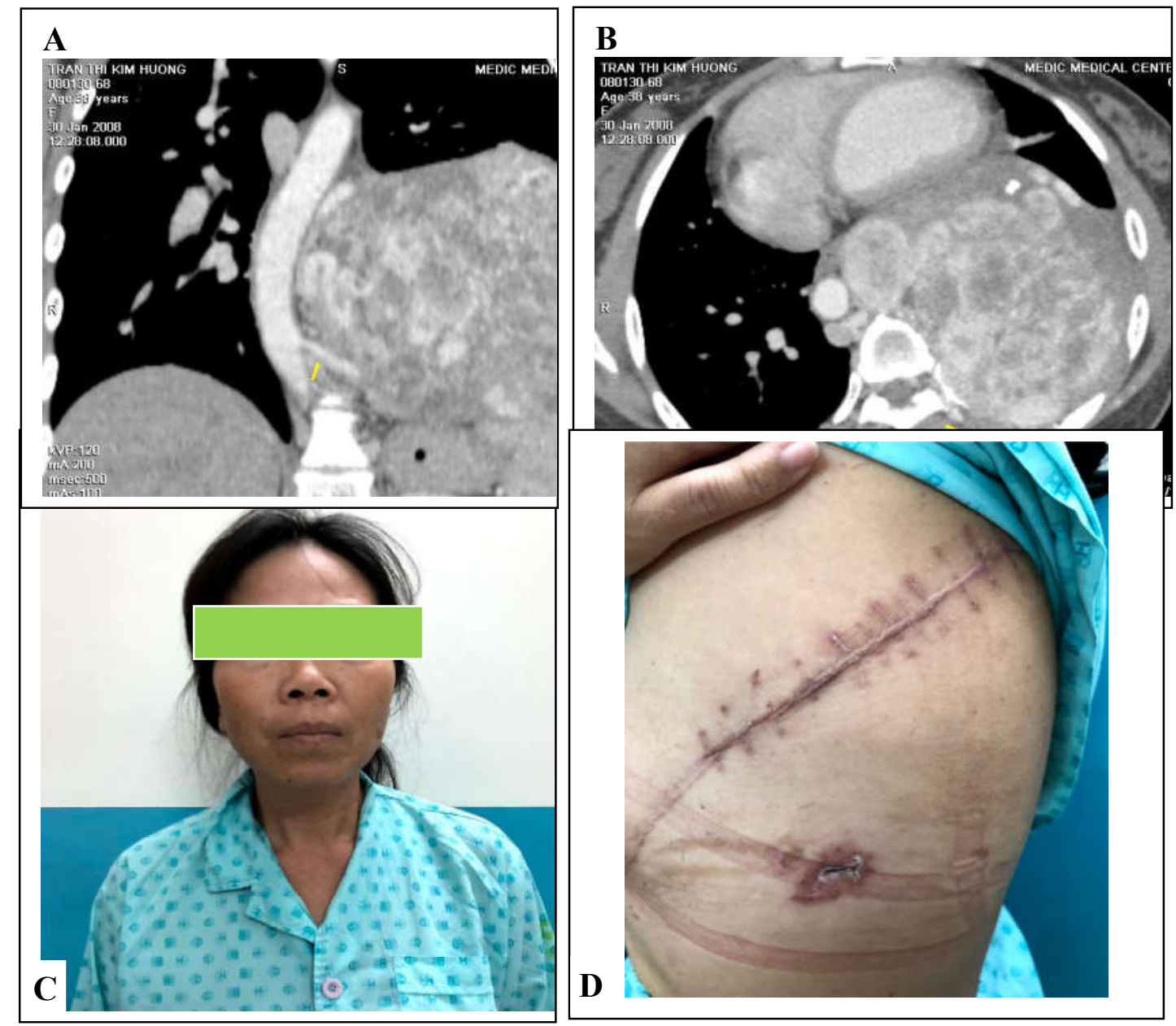

\section{Hình 2:}

A: MSCT lần mổ đầu: Khối bướu rất lớn ở phổi trái, chiếm hết lồng ngực trái

B: khối bướu đẩy trung thất qua phải. Khối bướu đậm độ không đều, có mạch máu lớn gần kề bên trong nên nghĩ là bướu mạch máu (Hemangioma).

C: BN Trần thi Kim H, 1970 ; D: Seo trên đường mở ngực cũ

Khoa lồng ngực đã cho làm xét nghiệm, không thấy các tổn thương khác, trừ bướu ở dưới thành ngực trái. Thử máu: nhóm máu $\mathrm{B}$, Hct $37,2 \%$, HGB 11,1 g/dL, Bạch cầu 12,24K/uL, PLT $265 \mathrm{~K} / \mathrm{uL},(9 / 10 / 2019)$. Sau mổ bạch cầu
18,32 K/ul, PLT $313 \mathrm{~K} / \mathrm{ul}$ (10/10/019). Ion đồ $\mathrm{Na}^{+} 134, \mathrm{~K}^{+} 4.1, \mathrm{Cl}^{-} 100, \mathrm{Ca}^{++} 106 \mathrm{mmol} / \mathrm{L}$ Nước tiểu: bình thường. Đàm: không thấy trực trùng kháng acid alcool (27/9/2019). SA doppler tim: EF 74\%. ECG Nhịp xoang. Chức năng phổi: 
bình thường, $X$ quang ngực: gãy cũ xương sườn 5-6 trái , mờ không đồng nhất đáy phổi trái, nghi ngờ là khối u.(7/10/2019). Sinh thiết xuyên thành ngực dưới hướng dẫn MSCT với kết quả GPB: Carcinoma tuyến biệt hóa kém .
Phẫu thuật lại ngày 17/10/2019 với phương pháp vô cảm: Mê NKQ. (Equipe mổ : GS Văn Tần, BS Nguyễn văn Việt Thành, BS Đòan Hùng Dũng; BS Gây mê: Nguyễn Cao Thúy Hằng, Tôn Thất Hùng).

Lý do phẫu thuật: Cắt bướu và 1 phần thùy dưới phổi trái
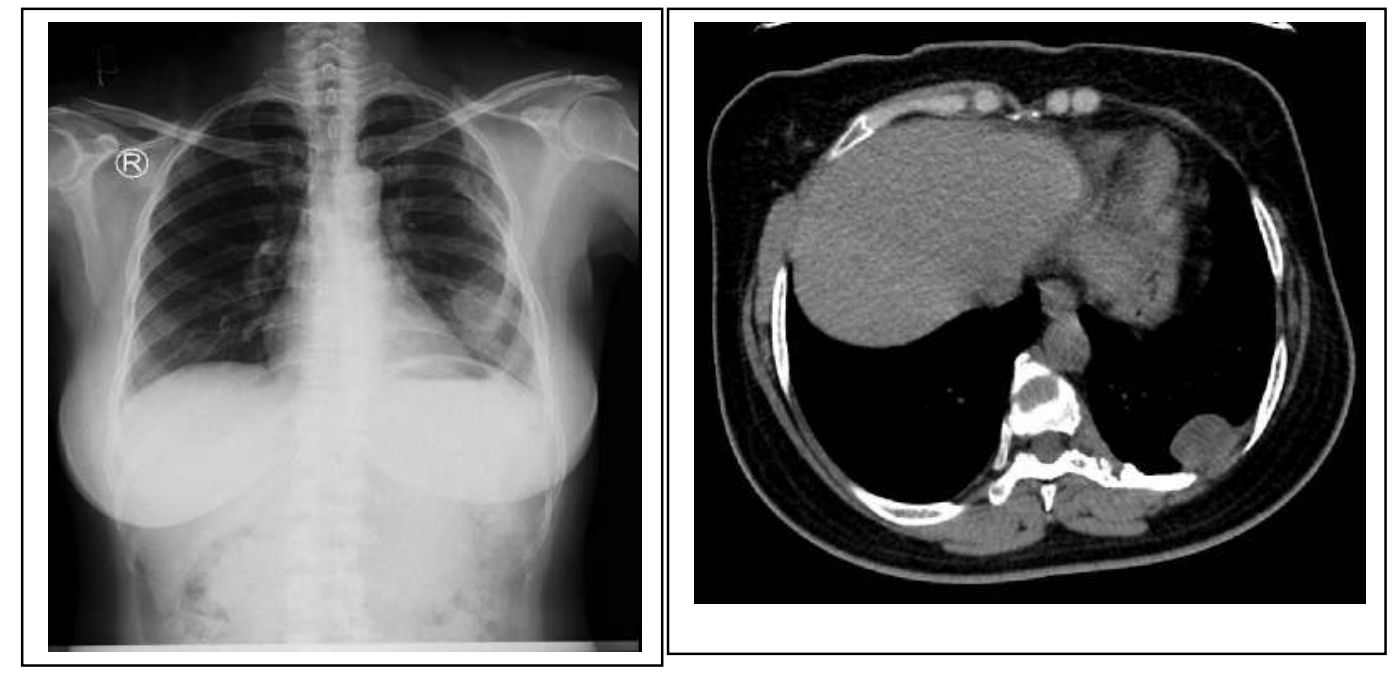

\section{Hình 3: X quang ngụ̣c thẳng và MSCT cho thấy bướu tái phát ở ngực trái}

Tư thế $\mathrm{BN}$ : nằm nghiêng phải 90 độ. Rạch da: Đường bên dài $12 \mathrm{~cm}$ theo đường cũ . Mở khoang liên sườn 5-6, vào ngực. Phổi dính nhiều vào thành ngực và phổi trái. Gở dính phổi vì bướu dính chặt vào thành ngực, bóc tách khó khăn gây vỡ bướu. Cắt trọn bướu và 1 phần thùy dưới phổi trái. Cầm máu cẩn thận, Khâu bằng Vicryl 3.0. Đặt dẫn lưu màng phổi . Thời gian phẫn thuật 100 phút, máu mất khoảng $200 \mathrm{ml}$.

Ban đầu mổ nội soi không thành do không thể làm xẹp phổi trái, phải hoản mổ. 1 tuần sau, lên lịch mổ lại. Đặt ống NG, chuẩn bị mổ mở vì thành ngực đã mổ lần trước nên phổi dính.

Giải phẫu bệnh mô bướu: Bướu lympho $\mathrm{B}$. Làm hóa mô miển dịch: Bướu mạch chu bào của phổi (hemangiopericytoma)

\section{BÀN LUẬN}

Bướu mạch chu bào phổi là u hiếm, có thể là lành hay ác $[1,2,3]$. Lần đầu, cắt bỏ bướu, không hóa trị vì định bệnh mô bướu lành tính. Sau 10 năm bướu tái phát và mổ lại tại BV Bình Dân, cắt bướu và 1 phần phổi thùy dưới trái. Mô bướu lần đầu là ung thư (sinh thiết qua kim theo $\mathrm{CT}$ ), lần sau là bướu lympho $\mathrm{B}$ tế bào lớn, hóa mô miển dịch là bướu mạch chu bào phổi. Vấn đề là sau mổ có hóa trị hay không, cần xem lại mô bướu.

Bướu nầy có thể có ở tuổi từ mới sanh đến 60, trên lý thuyết, bướu ở đâu có vi quản [7, $11,13,14]$, rất hiếm. Bướu xuất phát từ mô quanh mạch máu. Tế bào là tế bào cơ trơn thay đổi và có tính co dãn làm dãn nở vi quản. Khi xem lại 197 $\mathrm{BN}$, Stout chứng minh rằng, bướu thường ban đầu ở mô ngoại biên $[6,17]$. Bướu nầy phát xuất đầu tiên ở phổi thì thật là hiếm. Nhiều trường hợp (TH) không có triệu chứng khi dưới $5 \mathrm{~cm}$ đường kính và chỉ tìm thấy nhờ chụp hình phổi.

Stout $\mathrm{AF}$ và Murray MR, năm 1942 người đầu tiên nhận thấy khi mổ và định bệnh là 
hemangiopericytoma, với mô gốc từ tế bào quanh mạch máu Zimmerman. Họ mô tả 9 TH bướu chung quanh mao mạch [17], từ 1923.

Enzinger FM, Smith BH [7] chia bướu thành 2 nhóm, nhóm trẻ và nhóm người lớn. Nhóm trẻ thường tìm thấy ở đầu và cổ, các chi và thân, thường lành tính, ở người già thường ở trong hốc mủi và trong xoang mủi và các nơi khác. Ung thư gặp $1 \%$ ở mạch máu và $5 \%$ ở các sarcoma [15]. Bướu ở phổi rất hiếm, khoảng 145 $\mathrm{TH}$ trong $\mathrm{y}$ văn từ năm 1954 đến 2007 $[2,5,7,13,18]$. Ở phổi thường tuổi 50-60, nam nữ giống nhau. Triệu chứng chính là đau ngực, khó thở, ho và ho ra máu [5]. X quang phổi sẽ thấy bướu, có ít tràn dịch màng phổi. Mô bướu là một nhóm tế bào bao quanh các vi quản. Tế bào thì nhỏ với ít tế bào chất, nhân tròn. Nhuộm bạc thấy tế bào nằm ngoài mạch máu [12]. Căn cứ trên mô bướu, tác giả đã xếp nhóm I, nhóm II và nhóm III theo phân loại WHO năm 2016. Nhóm I xem như lành tính vì tế bào không thay đổi; Nhóm III gồm tế bào phát triển cao ( $>5$ per hpf); nhóm II có tiêu chuẩn anaplasic HPC, gần giống nhóm III. Tuổi TB 42,5 (60 bệnh nhân) [5].

Căn cứ theo phân loại WHO 2016, tác giả Sung [18] thấy nhóm I sau theo dõi 42,9 tháng, không tái phát vì tế bào không sinh mới, không có nhiều tế bào, và không có nhân bất thường . Nhóm II, điều trị có 8 tái phát (29,6\%), nhóm III cũng có 8 tái phát (61,5\%), nhưng không có ý nghĩa trên thống kê. Cũng theo tác giả, tử vong gồm có $1 \mathrm{TH}$ di căn ngoài sọ, $4 \mathrm{TH}$ di căn trong nảo, 1 TH chảy máu trong não, 1 TH chảy máu ở mô còn sót. Như vậy di căn ngoài sọ $5 \mathrm{TH}$ $(12,5 \%)$. Guthrie và CS báo cáo di căn ngoài sọ là kết quả của tăng tỉ lệ tử vong $[4,9]$. Ngoài ra, di căn ngoài sọ của nhóm tác giả tử vong 3 trên 6 bệnh nhân [9]. Di căn sớm nhất của nhóm tác giả là sau 7 đến 20 năm. Thời kỳ di căn dài nhất là 182,3 tháng. Do đó, nhóm I là không di căn, Nhóm III phát triển di căn rất nhanh. Nhóm II di căn trung bình [17].

Nguồn gốc thật của bướu không biết rõ, có thể bướu từ tế bào mesenchyme kém biệt hóa, vấn đề còn tranh cải $[5,7,11]$. Đa số tác giả xếp bướu vào nhóm sarcoma.

Riêng trường hợp của chúng tôi có thể thuộc nhóm II vì chúng tôi tìm thấy bướu di căn ở đáy phổi trái khoảng 8 năm. Về hóa trị, xử dụng Panzopanib theo Lee và cộng sự vì nguyên nhân có thể từ tyrosine, kinase inhibitors [14]. Các tác giả khác dùng Doxorubicin đơn độc hoặc phối hợp với Cisplatin, Etoposide, và Gemcitabin $[5,20]$
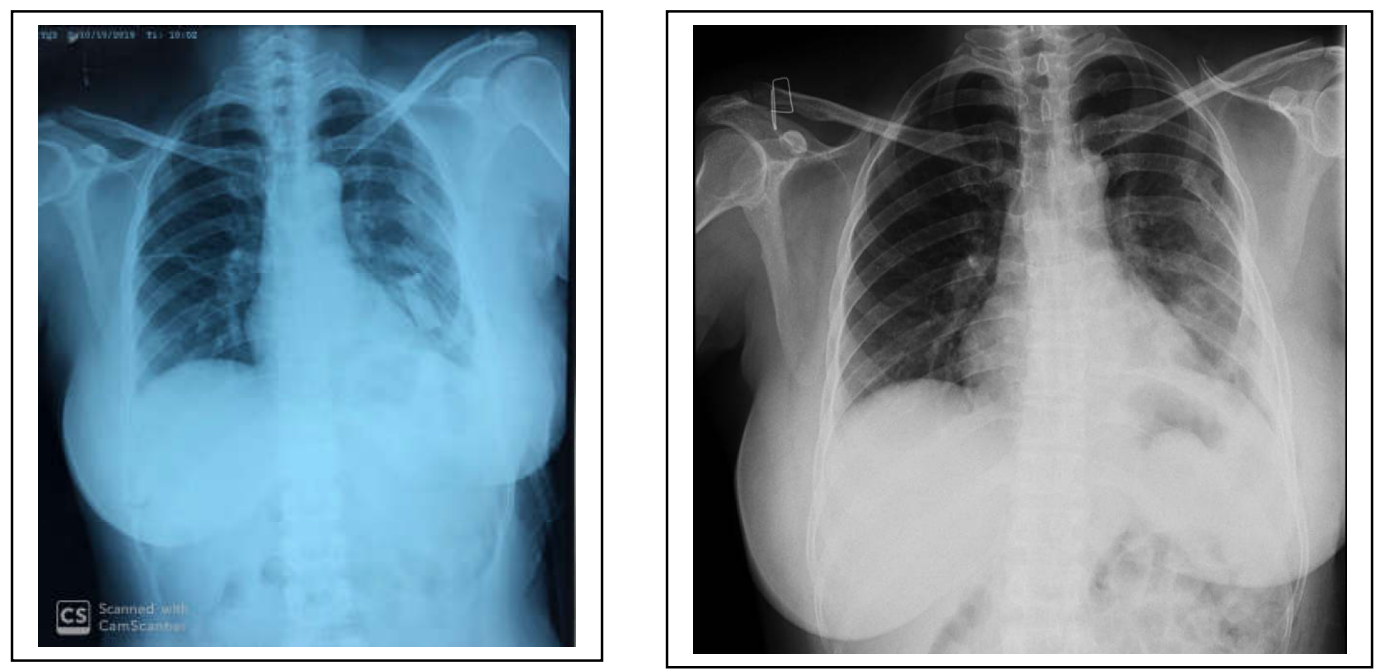

Hình 4: X quang phổi sau mổ và sau mổ 1 tháng 


\section{KẾT LUẬN}

Bướu có tế bào quanh mạch máu thật khó chẩn đoán. Chúng tôi ước lượng bệnh nhân $\mathrm{H}$. ở nhóm II. Nhóm II ở phổi di căn chậm cho nên sau 10 năm mới thấy bướu. Thật ra người bệnh cảm thấy nhức đầu, chóng mặt khoàng 2 năm trước nên chúng tôi nghĩ là sau 8 năm, có thể đã tái phát, di căn và thời kỳ đó bướu còn nhỏ, nên không biết vì lâm sàng khó phân biệt và nhất là không làm MSCT phổi.Phẫu thuật cắt trọn bướu nên thực hiện khi điều kiện cho phép.

\section{TÀI LIỆU THAM KHẢO}

1-Barjas R,Piccioni DE Malignant hemangiopericytoma: Treatment patterns and survival. J Clinical Oncology 35, no. 15_suppl. DOI: 10.1200/JCO.2017.35.15_suppl.e13520 .

2- Briselli M, Mark EJ, Dikerson GR: Solitaty fibrous tumor of the pleura, eight new cases and review of 360 cases in the literature. Cancer 1981; 47:2678-2689.

3- Chnaris A, Barberaki N, Efstarhieu A et al: Primary mediastinal hemangiopericytoma. World J Surg Oncol 2006, 4-23.

4- Damodaran O, Robbins P, Knuckey et al: Primary intracranien hemangiopericytoma, comparison of survival outcomes and metastatic potential in WHO grade II and III variants. $J$ Clin Neurosci 21:1310-1314, 2014

5- Fuijita A, Minase T, Takabatake H et al: A case of primary malignant hemangiopericytoma of the lung with marked response in combination chemotherapy with cisplatin, ifosfamide and gentamycine Japanese $J$ Cancer and Chemotherapy, 2001; 28:373-376.

6- Fletcher CDM: Diagnosis histopatology of tumor. $2^{\text {nd }}$ ed London, UK Churchill Livingstone, 2000:77-80.

7-Enzinger FM, Smith BH: Hemangiomapericytoma. An analysis of 106 cases. Hum pathol 1976, 7:61-82

8- Gengler C, Guillon I.: Solitary fibrous tumor and hemangiopericytoma evolution of a concept. Histopathology 2006; 48:63-74.

9- Guthrie BL, Ebersold MJ, Scheithauer BW et al: Meningeal hemangiopericytoma histopathological feature, treatment, and longterm follow up of 44 cases. Neurosurgery 25:514-522, 1989.

10- Ghose A, Guha G, Kundu R et al: CNS hemangiopericytoma: a systemic review of 523 patients. Am J clin 40:223-227, 2017.

11- Hallen M, Parada LA, Goeunova L et al: Cytogenic abnormalities in a hemagiopericytoma of the spleen. Cancer Genet Cytogenet 2002,136: 62-65

12- Hugle WP: Malignant hemangiopericytoma. A clinical overview and case study. Clin J Oncol 2003:7:57-62.

13- Kaminska I, S-Wojcik E, Kudsinski P et al: Primary lung hemangiopericytoma: a rare neoplasm with a long course of recurrence over many years. Pneumonol Alergol Pol 2001,69: 290-294.

14- Lee SJ, Kim ST, Park SH et al: Successful use of pazopanib for treatment of refractory metastatic hemangiopericytoma. Division of Hematology-Oncology, dpt of Medecine Samsung, Seoul 135-710, Korea.

15- Penel N, Amela EY, Decanter G, Robin YM, Marec- Berard P. Solitary Fibrous Tumors 
and So-Called Hemangiopericytoma. Volume 2012, classification. J Neurosurg, March 9, 2018. Article ID 690251, doi:10.1155/2012/69025.

19- Van de Rijn M, Lombard CM, Rouse

16- Radulescu D, Pripon S, Ciuleanu TE, et $\mathrm{RV}$ : Expression of CD34 by solidary fibrous al: Malignant primary tumor with tumors of pleura, mediastinum and lung. Am $J$ hemangiopericytoma-like feature: conventional Surg Pathol 1994,18:815-820. hemangiopericytoma versus solitary fibrous tumor. Clinical lung cancer, vol 8, No 8, 504-508, 2007.

20- Tulay Akman, Ahmet Alacacioglu, 17- Stout AP and Murray MR: Hemagiopericytoma a vascular tumor featuring Zimmerman's pericytes. Ann Surg 1942, 116:26-32.

18- Sung KS, Moon JH, Kim EH et al: Solitary fibrous tumor/hemangiopericytoma. Treatment results based on the 2016 WHO Devrim Dolek, Tugba Unek, Duygu Gurel, Ahmet Ugur Yilmaz, and Ahmet Onen . Malign Recurrence of Primary Chest Wall Hemangiopericytoma in the Lung after Four Years : A Case Report and Review of the Literature. Hindawi, Volume 2014, Article ID 470268, http://dx.doi.org/10.1155/2014/470268. 